\title{
ISOLATION, IDENTIFICATION AND PREVALENCE OF PARASITES ON OREOCHROMIS NILOTICUS FROM THREE SELECTED RIVER SYSTEMS
}

\author{
ASHADE, O.O., OSINEYE, O. M. AND KUMOYE, E. A. \\ ${ }^{1}$ Department of Biological science, Yaba College of Technology, Lagos \\ ${ }^{2}$ Department of Fisheries Technology, Federal College of Fisheries and Marine Technology, Lagos.
}

Copyright 2010, Fisheries Society of Nigeria.

This paper was prepared for presentation at the $25^{\text {th }}$ Annual International Conference and Exhibition in Administrative Staff College of Nigeria (ASCON), Topo-Badagry, Lagos, Nigeria, $25^{\text {th }}-29^{\text {th }}$ October, 2010.

This paper was selected for presentation by an FISON Program Committee following review of information contained in an abstract submitted by the author(s). Contents of the paper, as presented, have not been reviewed by the Fisheries Society of Nigeria and are subject to correction by the author(s). The material, as presented, does not necessarily reflect any position of the Fisheries Society of Nigeria, its officers, or members. Papers presented at FISON meetings are subject to publication review by Editorial Committees of the Fisheries Society of Nigeria Electronic reproduction, distribution, or storage of any part of this paper for commercial purposes without the written consent of the Fisheries Society of Nigeria is prohibited. Permission to consent of the Fisheries Society of Nigeria is prohibited. Permission to reproduce in print is restricted to an abstract of not more than 300 words; illustrations may not be copied. The abstract must contain conspicuous acknowledgement of where and by whom the paper was presented. Write Lagos.
Librarian, Fisheries Society of Nigeria (FISON), P. O. Box 2607 Apapa,

\section{ABSTRACT}

The prevailence of protozoan and helminthic parasite species occurring on and in the lnternal organs of Oreochromis niloticus were studied. Twenty samples of a mixture of adult and juvenile individuals of Oreochromis niloticus were randomly obtained from fishermen landing at the jetties of Epe water side, Ikorodu (Odoguyan) river and a brackish water (makoko), between September and and October, 2009, during a period of low rainfall. Samples were eviscerated and the parasites were excised, identified and each specie of parasites was counted. Most of the parasites encountered were of the Protozoa, manogenea, Digenea, Cestoda and Nematoda groups. The infestation was predominantly by Nematoda species and followed by protozoan species. Protozoan parasites like Trichodina sp and Ichyobodo sp were found to be prevalent, in varying magnitude, in most of the fish samples without clear age discrimination. The study reveals that the prevailence of parasites infestation increases with increasing length, size and age of the fish host and different pars of the fish.
Keywords: parasite, identification, fish selected river, Lagos.

\section{INTRODUCTION}

Fish is a food consumed by many species, including humans, the word fish refers to both the animal and to the food prepared from it. Three quarter of the earth surface is covered by water, so fish has been an important part of the diets of human in almost all continents of the world. Fish is a cheap and important source of protein; it contains lipids, minerals and vitamins. Fish occupies several different leveled of the aquatic food chain and makes up more than $40 \%$ of the world vertebrate species. Fish interracts with the various levels of food chain and influence the structures of lakes, streams and estuaries, since they are usually restricted to a particular mode of life related to their food source and reproductive requirement.

Many fish species have been found to harbour protozoan and plenty of helminth parasites on their skin and /or under their scales. (George, 2002). Parasitology has always been a discipline in which purely academic studies of the evolution of parasites and their life-cycles have progressed as a necessary complement to the study of the pathology and, control of the major tropical diseases of human and their livestocks.

Indeed, the most striking feature of parasitology is the diversity of parasites in the warm tropical regions of the world and the frightening levels of debilitation and misery they cause. Similarly, the study of parasite population dynamics has 
developed within a solid theoretical framework (Anderson and May, 1979). Fish parasites have logically received greatest attention in past researches. Parasites are organism that inhabit, at sometime during their life-cycle, the body of another larger animal, thereby causing various diseases (George, 2002). Fishes, like other animals are exposed and susceptible to a wide range of microbial infections. These microbial infections are caused by organisms which are referred to as parasites. Fish parasites could be as a result of density of stocking, poor condition of farming, lack of proper husbandry and stress (George, 2002). This study would serve as baseline data for further research works that have to do with the distribution of fish parasites from these rivers and water bodies.

\section{MATERIALS AND METHODS}

Three water bodies in Lagos were chosen for the collection of adult and juvenile samples of the Oreochromis niloticus for the isolation and identification of parasites found on them and within their organs.

The three water bodies are Epe water site (a brackish water), Ikorodu (a fresh water) areas of Lagos State that are connected by the Ogun river as well as the network of Lagos Lagoons.

\section{Sample Collection}

Twenty samples of a mixture of adult and juvenile individuals of Oreochromis niloticus were obtained weekly for six weeks from fishermen landing at the jetties of these towns already identified. Sample collections and immediate excision of parasites were carried out in between weeks of September and October, 2009, during a period of low rainfall.

\section{Materials}

Light microscope, dissecting kit, a pair of scissors, wash-glass, petri-dishes, glass slides, coverships, pant brush, saline water, alcohol, formation acetic acid solution and wright-Griemsa stain.

\section{Methodology}

Isolation and identification of parasitesprotozoa, monogenea, digenea, cestoda and nematode, from fish was done as described by Roberts (1978). 


\section{RESULT}

TABLE 1: Prevalence of Parasite species found on Oreochromis niloticus (Week 1)

\begin{tabular}{|c|c|c|c|c|c|c|c|c|}
\hline \multirow[t]{2}{*}{ CLASS } & \multicolumn{2}{|l|}{ EPE } & \multicolumn{2}{|c|}{ IKORODU } & \multicolumn{2}{|c|}{ MAKOKO } & \multicolumn{2}{|c|}{ OVERALL TOTAL } \\
\hline & Count & $\%$ & Count & $\%$ & Count & $\%$ & Count & $\%$ \\
\hline PROTOZOA & 0 & 0 & 1 & 2.9 & 1 & 2 & 2 & 1.9 \\
\hline \multicolumn{9}{|l|}{ chilodonella sp. } \\
\hline Ichyophthirius multifilis & 1 & 4.4 & 1 & 2.9 & 1 & 2 & 3 & 2.8 \\
\hline Trichodina sp. & 2 & 8.7 & 7 & 20.6 & 15 & 29.4 & 24 & 22.2 \\
\hline Epistylis sp. & 2 & 8.7 & 1 & 2.9 & 1 & 2 & 4 & 3.7 \\
\hline Ichyobodo sp. (Costia) & 1 & 4.4 & 2 & 5.8 & 3 & 5.9 & 6 & 5.6 \\
\hline MONOGENEA & & & & 2.9 & 2 & 3.9 & 3 & 2.8 \\
\hline$\overline{\text { Gyrodactylus }}$ & 0 & 0 & 1 & & & & & \\
\hline Macrogyrodactylus sp. & 0 & 0 & 0 & 0 & 0 & 0 & 0 & 0.0 \\
\hline Dactylogyrus sp. & 1 & 4.4 & 2 & 5.8 & 3 & 5.9 & & \\
\hline DIGENEA & & & & & & & 6 & 5.6 \\
\hline \multicolumn{9}{|l|}{$\overline{\text { Clinostomum }}$} \\
\hline Marginatum & 3 & 13 & 1 & 2.9 & 0 & 0 & & \\
\hline Heterophyes sp. & 0 & 0 & 0 & 0 & 0 & 0 & 4 & 3.7 \\
\hline CESTODA & & & & 0 & 0 & 0 & 0 & 0.0 \\
\hline$\overline{\text { Diphylobothrium latum }}$ & 0 & 0 & 0 & & & & & \\
\hline Bothricepholus sp. & 1 & 4.4 & 3 & 8.8 & 5 & 9.8 & 0 & 0.0 \\
\hline NEMATODES & & & & 2.9 & 1 & 2 & 9 & 8.3 \\
\hline$\overline{\text { Camallanus sp. }}$ & 4 & 17.4 & 1 & & & & & \\
\hline Capillaria sp. & 3 & 13 & 8 & 23.5 & 10 & 19.6 & 6 & 5.6 \\
\hline Eustrongyloides sp. & 1 & 4.4 & 1 & 2.9 & 1 & 2 & 21 & 19.4 \\
\hline Trichuris sp. & 0 & 0 & 0 & 0 & 0 & 0 & 3 & 2.8 \\
\hline Philometra sp. & 0 & 0 & 0 & 0 & 0 & 0 & 0 & 0.0 \\
\hline Contracaecum sp. & 4 & 17.4 & 5 & 14.7 & 8 & 15.7 & 0 & 0.0 \\
\hline TOTAL & 23 & 100 & 34 & 100 & 151 & 100 & 108 & 100 \\
\hline RELATIVE PERCENTAGE & 21.9 & & 31.5 & & 47.2 & & 100 & \\
\hline
\end{tabular}




\section{RESULTS}

TABLE 2: Prevalence of Parasite species found on Oreochromis niloticus (Week 2)

\begin{tabular}{|c|c|c|c|c|c|c|c|c|}
\hline \multirow[t]{2}{*}{ CLASS } & \multicolumn{2}{|l|}{ EPE } & \multicolumn{2}{|c|}{ IKORODU } & \multicolumn{2}{|c|}{ MAKOKO } & \multicolumn{2}{|c|}{ OVERALL TOTAL } \\
\hline & Count & $\%$ & Count & $\%$ & Count & $\%$ & Count & $\%$ \\
\hline \multicolumn{9}{|l|}{ PROTOZOA } \\
\hline$\overline{\text { Chilodonella sp. }}$ & 1 & 4.5 & 1 & 2.8 & 0 & 0 & 2 & 1.8 \\
\hline Ichyophthirius multifilis & 1 & 4.5 & 1 & 2.8 & 1 & 1.9 & 3 & 2.7 \\
\hline Trichodina sp. & 5 & 22.7 & 15 & 41.7 & 20 & 37.7 & 40 & 36 \\
\hline Epistylis sp. & 1 & 4.5 & 1 & 2.8 & 1 & 1.9 & 3 & 2.7 \\
\hline Ichyobodo sp. (Costia) & 1 & 4.5 & 1 & 2.8 & 1 & 1.9 & 3 & 2.7 \\
\hline \multicolumn{9}{|l|}{ MONOGENEA } \\
\hline$\overline{\text { Gyrodactylus }}$ & 0 & 0 & 2 & 5.5 & 4 & 7.6 & 6 & 5.4 \\
\hline Macrogyrodactylus sp. & 0 & 0 & 0 & 0 & 0 & 0 & 0 & 0.0 \\
\hline Dactylogyrus sp. & 1 & 4.5 & 1 & 2.8 & 1 & 1.9 & 3 & 2.7 \\
\hline \multicolumn{9}{|l|}{ DIGENEA } \\
\hline$\overline{\text { Clinostomum Marginatum }}$ & 3 & 13.6 & 1 & 2.8 & 1 & 1.9 & 5 & 4.5 \\
\hline Heterophyes sp. & 0 & 0 & 0 & 0 & 0 & 0 & 0 & 0.0 \\
\hline \multicolumn{9}{|l|}{ CESTODA } \\
\hline Diphylobothrium latum & 0 & 0 & 0 & 0 & 0 & 0 & 0 & 0.0 \\
\hline Bothricephalus sp. & 1 & 4.5 & 1 & 2.8 & 2 & 3.8 & 4 & 3.6 \\
\hline \multicolumn{9}{|l|}{ NEMATODES } \\
\hline$\overline{\text { Camallanus sp. }}$ & 1 & 4.5 & 2 & 5.5 & 4 & 7.6 & 7 & 6.3 \\
\hline Capillaria sp. & 5 & 22.7 & 8 & 22.2 & 15 & 28.3 & 28 & 25.2 \\
\hline Eustrongyloides sp. & 1 & 4.5 & 1 & 2.8 & 1 & 1.9 & 3 & 2.7 \\
\hline Trichuris sp. & 0 & 0 & 0 & 0 & 0 & 0 & 0 & 0.0 \\
\hline Philometra sp. & 0 & 0 & 0 & 0 & 0 & 0 & 0 & 0.0 \\
\hline Contracaecum sp. & 1 & 4.5 & 1 & 2.8 & 2 & 3.8 & 4 & 3.6 \\
\hline TOTAL & 22 & 100 & 36 & 100 & 53 & 100 & 111 & 100 \\
\hline \multicolumn{9}{|l|}{ RELATIVE } \\
\hline PERCENTAGE & 19.8 & & 32.4 & & 47.8 & & & \\
\hline
\end{tabular}




\section{RESULTS}

TABLE 3: Prevalence of Parasite species found on Oreochromis niloticus (Week 3)

\begin{tabular}{|c|c|c|c|c|c|c|c|c|}
\hline \multirow[t]{2}{*}{ CLASS } & \multicolumn{2}{|l|}{ EPE } & \multicolumn{2}{|c|}{ IKORODU } & \multicolumn{2}{|c|}{ МАKOKO } & \multicolumn{2}{|c|}{ OVERALL TOTAL } \\
\hline & Count & $\%$ & Count & $\%$ & Count & $\%$ & Count & $\%$ \\
\hline \multicolumn{9}{|l|}{ PROTOZOA } \\
\hline Chilodonella sp. & 1 & 4.2 & 1 & 3.1 & 1 & 2.0 & 3 & 2.7 \\
\hline Ichyophthirius multifilis & 0 & 0 & 1 & 3.1 & 3 & 6 & 4 & 3.6 \\
\hline Trichodina sp. & 5 & 20.8 & 8 & 25 & 12 & 24 & 25 & 22.7 \\
\hline Epistylis sp. & 1 & 4.2 & 1 & 3.1 & 1 & 2 & 3 & 2.7 \\
\hline Ichyobodo sp. (Costia) & 0 & 0 & 1 & 3.1 & 1 & 2 & 2 & 1.8 \\
\hline MONOGENEA & & & & & & & & \\
\hline Gyrodactylus & 1 & 4.2 & 1 & 3.1 & 2 & 4 & 4 & 3.6 \\
\hline Macrogyrodactylus sp. & 0 & 0 & 0 & 0 & 0 & 0 & 0 & 0.0 \\
\hline $\begin{array}{l}\text { Dactylogyrus sp. } \\
\text { DIGENEA }\end{array}$ & 1 & 4.2 & 1 & 3.1 & 2 & 4 & 4 & 3.6 \\
\hline$\overline{\text { Clinostomum Marginatum }}$ & 3 & 12.5 & 1 & 3.1 & 0 & 0 & 4 & 3.6 \\
\hline $\begin{array}{l}\text { Heterophyes sp. } \\
\text { CESTODA }\end{array}$ & 0 & 0 & 0 & 0 & 0 & 0 & 0 & 0.0 \\
\hline Diphylobothrium latum & 0 & 0 & 0 & 0 & 0 & 0 & 0 & 0.0 \\
\hline $\begin{array}{l}\text { Bothricephalus sp. } \\
\text { NEMATODES }\end{array}$ & 1 & 4.2 & 2 & 6.3 & 4 & 8 & 7 & 6.4 \\
\hline Camallanus sp. & 1 & 4.2 & 2 & 6.3 & 4 & 8 & 7 & 6.4 \\
\hline Capillaria sp. & 4 & 16.7 & 7 & 21.9 & 10 & 20 & 21 & 19.1 \\
\hline Eustrongyloides sp. & 1 & 4.2 & 0 & 0 & 2 & 4 & 3 & 2.7 \\
\hline Trichuris sp. & 0 & 0 & 0 & 0 & 0 & 0 & 0 & 0.0 \\
\hline Philometra sp. & 0 & 0 & 0 & 0 & 0 & 0 & 0 & 0.0 \\
\hline Contracaecum sp. & 5 & 20.8 & 6 & 18.8 & 8 & 16 & 19 & 17.3 \\
\hline TOTAL & 24 & 100 & 32 & 100 & 50 & 100 & 110 & 100 \\
\hline $\begin{array}{l}\text { RELATIVE } \\
\text { PERCENTAGE }\end{array}$ & & & & & & & & \\
\hline
\end{tabular}




\section{RESULTS}

TABLE 4: Prevalence of Parasite species found on Oreochromis niloticus_ (Week 4)

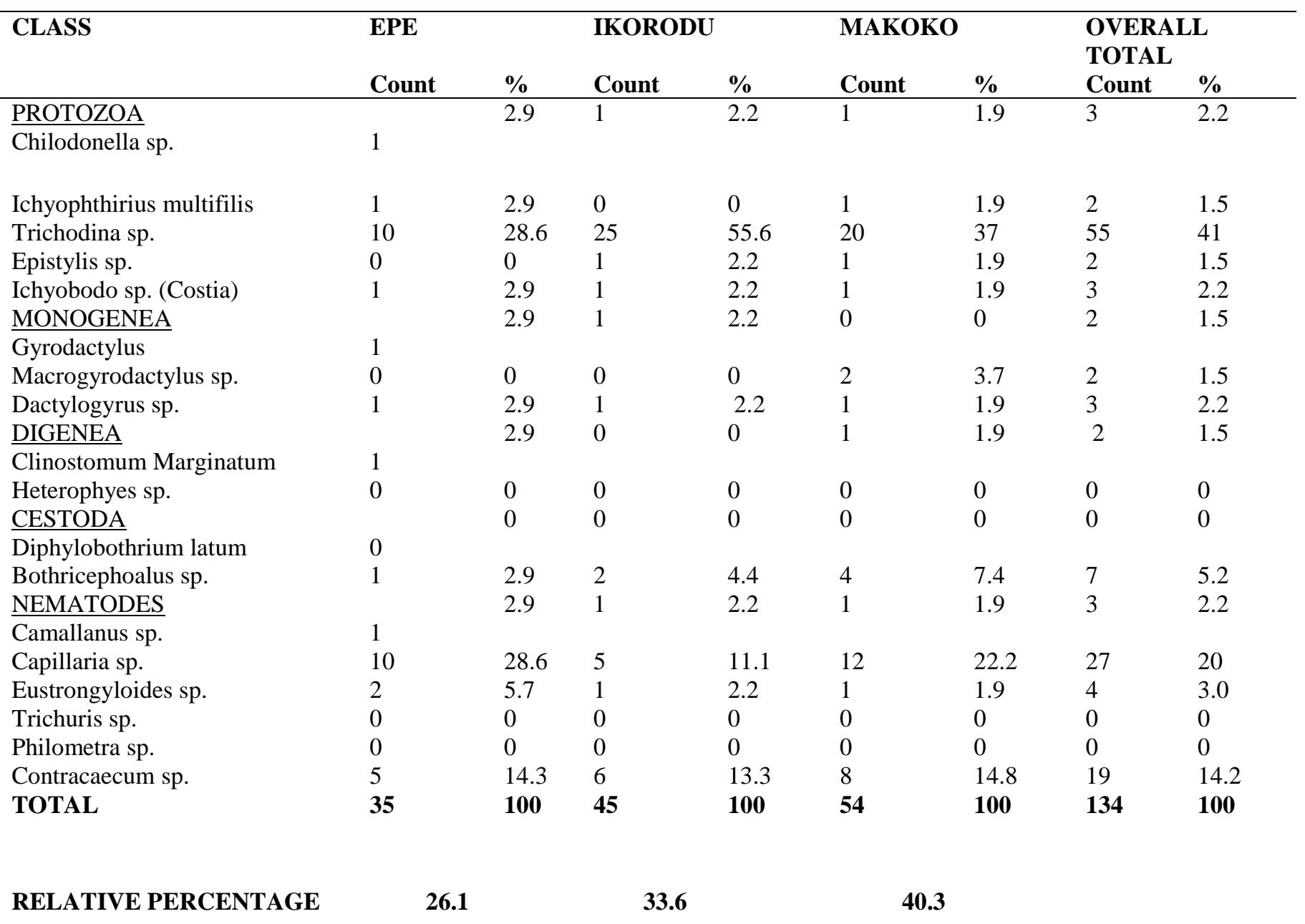


TABLE 5a: COMPARISON OF DEGREE OF PARASITIC INFESTATION AMONG THE THREE WATER BODIES

\begin{tabular}{|c|c|c|c|c|c|}
\hline PERIOD & & EPE & IKORODU & MAKOKO & SEM \\
\hline WEEK 1 & & $23^{c}$ & $34^{\mathrm{b}}$ & $51^{\mathrm{a}}$ & 1.27 \\
\hline WEEK 2 & Sept.2009 & $22^{c}$ & $36^{\mathrm{b}}$ & $53^{\mathrm{a}}$ & 1.29 \\
\hline WEEK 3 & & $24^{\mathrm{c}}$ & $32^{\mathrm{b}}$ & $50^{\mathrm{a}}$ & 1.20 \\
\hline WEEK 4 & Oct.2009 & $35^{\mathrm{c}}$ & $45^{\mathrm{b}}$ & $54^{\mathrm{a}}$ & 0.97 \\
\hline
\end{tabular}

TABLE 5b: VALUES ON TABLE 5a IN PERCENTAGES

\begin{tabular}{|c|c|c|c|c|c|}
\hline PERIOD & & EPE & IKORODU & MAKOKO & SEM \\
\hline WEEK 1 & & $21.9^{c}$ & $31.5^{\mathrm{b}}$ & $47.2^{\mathrm{a}}$ & 0.78 \\
\hline WEEK 2 & \$ept.2009 & $19.8^{\mathrm{c}}$ & $32.4^{\mathrm{b}}$ & $47.8^{\mathrm{a}}$ & 0.81 \\
\hline WEEK 3 & & $21.8^{\mathrm{c}}$ & $29.1^{\mathrm{b}}$ & $45.5^{\mathrm{a}}$ & 0.69 \\
\hline WEEK 4 & Oct.2009 & $26.1^{\mathrm{c}}$ & $33.6^{\mathrm{b}}$ & $40.3^{\mathrm{a}}$ & 0.32 \\
\hline
\end{tabular}

Table $5 \mathrm{a}$ and $5 \mathrm{~b}$ reveal that brackish water was more infested with parasitic organisms than the freshwater bodies this can be attributed to the fact there is a denser population around the Makoko water body, relative to those of the two other locations (Epe and Ikorodu), besides, brackish water bodies suffer more from pollution than fresh water bodies, especially where the brackish water is surrounded by a dense population, this is similar to the observation of Osineye etal (2009). 
TABLE 6a: COMPARISON_OF DEGREES OF PARASITIC INFESTATION AMONG THE FOUR PERIOD OF STUDY

\begin{tabular}{llllll}
\hline WATER BODIES & WEEK 1 & WEEK 2 & WEEK 3 & WEEK 4 & SEM \\
EPE & $23^{\mathrm{b}}$ & $22^{\mathrm{b}}$ & $24^{\mathrm{b}}$ & $35^{\mathrm{a}}$ & 0.21 \\
IKORODU & $34^{\mathrm{b}}$ & $36^{\mathrm{b}}$ & $32^{\mathrm{b}}$ & $45^{\mathrm{a}}$ & 0.10 \\
MAKOKO & $51^{\mathrm{a}}$ & $53^{\mathrm{a}}$ & $50^{\mathrm{a}}$ & $54^{\mathrm{a}}$ & 0.01 \\
\end{tabular}

TABLE 6b: VALUES ON TABLE 6a IN PERCENTAGES

\begin{tabular}{|c|c|c|c|c|c|}
\hline WATER BODIES & WEEK 1 & WEEK 2 & WEEK 3 & WEEK 4 & SEM \\
\hline EPE & $21.9^{\mathrm{b}}$ & $19.8^{\mathrm{b}}$ & $21.8^{\mathrm{b}}$ & $26.1^{\mathrm{a}}$ & 0.01 \\
\hline IKORODU & $31.5^{\mathrm{b}}$ & $32.4^{\mathrm{a}}$ & $29.1^{\mathrm{b}}$ & $33.6^{\mathrm{a}}$ & 0.03 \\
\hline МАKOKO & $47.2^{\mathrm{a}}$ & $47.8^{\mathrm{a}}$ & $45.5^{\mathrm{a}}$ & $40.3^{b}$ & 0.05 \\
\hline
\end{tabular}

Table 6a \& b reveal that parasitic infestation of water bodies increases with advancing dry season - rainfall does a lot of cleansing to water bodies. Volumes of waters decrease with advancing dry season, thus increasing the population of parasitic organisms per unit volume of water, as recorded by Osineye et al (2009). 


\section{DISCUSSION}

The essence of constant surveillance of food-borne parasites and their epidemiological distribution can never be over emphasized in developing countries such as Nigeria. This is more so when literacy level and awareness of basic hygiene and methods of limiting the spread of these food-borne parasites are low. Fish remains one of the most highly sought after food items in many Nigerian dishes. It then remains very important that epidemiological surveys of the parasites borne by many of the popular fish species in our markets and landing sites, as arranged by the choice of Epe water-side, Ikorodu and Makoko, be adequately studied and well documented. It is therefore a shortcoming that fish is not included in food items and living organisms that are quarantined and adequately monitor across border. This study is very important first step towards proper wild fish stock management and the control of many of the human diseases caused by some of the fish borne disease causing agents.

This study showed a preponderance of some protozoan parasites for a given tilapia species host at some sampling location than for others.

The study showed that Trichodina $\mathrm{Sp}$ was very prevalent and abundant, all the tilapia species bone Trichodina $\mathrm{sp}$ at all the locations throughout the study period. While there is no categorical evidence that Trichodina do not cause any humanly known disease, the fact, that their method of attacking fish host skin and causing dermal erosion may indicarte other kind of secondary impacting pathogens that may predispose man to novel diseases. This is in clear agreement with previous studies carried out by Abaladejo and Arthur (1989).

According to Paperna (1980) the cichlids, habour majority of the infection which include the adult digenea infecting different tissues of the body; trematode metercercaria of the family clinostomidae encysing in tissue; and adult monogenea of the families, Dactylogridae and Gyrodactylidae infecting the gills and the skin, a similar observation was made in this study, where trematodes were located in the gills and skin of trilapia species. Kabaya (1985) and Paperna (1996) also reported excessive mucus secretion, epithelial proliferation and dermal erosion of fin fish association with the pathology of gyrodactylus sp.

This shows that it could be easy to identify fish samples with compromised dermal tissues that may bear Gyrodactylus sp and avoid them during market purchases in order to prevent human transmission of possible infection.

Clinostomum

$\underline{\text { marginatum, }}$

Bothriocephalus sp Camallanus $\mathrm{sp}$, capillaria sp, Enstrongylides sp and contracaecum sp were found parasitizing Oreopchromis niloticus, this observation agrees with the findings of Paperna (1980), Awachire (1966).

Nematode parasites were found in the intestines of the fish host as earlier observed by Okaka and Omoigberale (2002), who record nematode as the most common parasites infecting $18.6 \%$ of the fish population.

During this study, it was also observed that adult fishes have more susceptibility to parasitic infections than juveniles and this corroborates the finding of Torres et al (1979) who reported that the longer and bigger the fish, the greater the susceptibility to parasitic infections.

\section{RECOMMENDATION}

It is recommended that this study be continued and widened for greater number of fish species as are found in many Nigerian diets. For the control of parasites in fish culture system, the following recommendations are made:-

* The lining of ponds with slaked line, (for areas that have acidic condition), before stocking.

* Early detection of signs of parasitic problems by constant surveillance and observation of 
the behaviour in rivers and reservoirs.

* Removal of weeds and various types of vegetation to ensure that parasites such as leches and snails (intermediate hosts) of digenean flukes are kept under control

* Training of competent scientists to manage all commercial fish farms and reservoirs.

* The control of fish density, selective cropping and prompt removal of infected fish to avoid rapid spread to other fishes.

\section{CONCLUSION}

The economic impact of these parasites on fish as an article of trade from our inland and coastal waters in comparison to their endemic nature in fish culture system would lead to better policy decision on how to protect Nigeria's aquatic resources. This all the more important when one considers the expected hostile reactions of European countries to the important fish and fish products from Nigeria based on heavy parasitic infestation in the absence of any scientific study quantifying and controlling it. Therefore, the ultimate solution to most of these problems lies in "prevention is better than cure". A total and comprehensive knowledge of the biology of host-parasite relationship within the culture system is therefore imperative.

\section{REFERENCES}

Albaladejo, J.D and J. R. Arthur (1989): Some Trichodinis (Protozoa: Ciliophora; partitrichida) from freshwater fishes imported into the Philippines, Asia Fisheries Scicule, 3: 1-25.

Anderson, R.M. and R.M. May, Co. (1979). Population biology of infections diseases: Part 1, Nature 280: 361 .
Awachie, J.B.E. (1966). Preliminary notes on the parasites of fish in the area of the Kainji Reservoir, in the first scientific report of the Kainji Biological Research Team. EditWhite- Liverpool: Biological Research Team, Kainji 69pp.

George, W.L. (2002) Angler's Guide to fish diseases and parasites. University of George, College of Agricultural and Environmental Sciences, Co-operative 7pp.

Kabata, Z.(1985). Parasites and diseases of fish cultured in the tropics. Taylor and Francis (Printers) limited London and Philadelphia. 318pp.

Okaka,C.E. and O.M Omoigberale (2002). Parasites of fishes of Okhuaohe River, Edo State. African Scientist 3 (1): 1-2.

Osineye, O.M, Ashade, O.O. and A.K Odunlade (2009). Isolation, ldentification and prevailence of parasites on clarias gariepinus from four selected river systems. Journal of Research in Bioscience, Vol. 6. No 2: 100-105.

Paperna, I.(1980). Parasites, infections and diseases of fish in Africa. CIFA Tech. paper 7,FAO, Rome, Italy 200pp.

Paperna, I.(1996). Parasites, infections and diseases of fish in Africa-An update, CIFA Tech. paper, 31, FAO, Rome, Italy 200pp.

Roberts, R.J.(1978). Isolation and identification of parasitic organisms. Fish pathology 2 (1) 209.

Torres, P., Contreras, B., Figuerga, L. Franjola R. Gonzaleh, H. and R. Martin (1979). Research on Pseudophyllidea from the South of Chile. Preliminary investigation on infection of pherocercoids of Diphyllobotrium sp in Salmo gairdneruii from catalquen lake. Chile, 32: 73-80. 